\title{
Survival of three species of anuran metamorphs exposed to UV-B radiation and the pathogenic fungus Batrachochytrium dendrobatidis
}

\author{
T. S. Garciaa ${ }^{1,2,}$, J. M. Romansic ${ }^{1}$, A. R. Blaustein ${ }^{1}$ \\ ${ }^{1}$ Department of Zoology, 3029 Cordley Hall, Oregon State University, Corvallis, Oregon 97331-2914, USA \\ ${ }^{2}$ Present address: Department of Fisheries and Wildlife, 104 Nash Hall, Oregon State University, Corvallis, \\ Oregon 97331-3803, USA
}

\begin{abstract}
When exploring the possible factors contributing to population declines, it is necessary to consider multiple, interacting environmental stressors. Here, we investigate the impact of 2 factors, ultraviolet radiation and disease, on the survival of anuran amphibians. Exposure to ultraviolet-B (UV-B) radiation increases mortality and results in various sub-lethal effects for many amphibian species. Infectious diseases can also negatively impact amphibian populations. In this study, we exposed metamorphic individuals (metamorphs) to both UV-B and Batrachochytrium dendrobatidis (BD), a fungal pathogen and cause of the disease chytridiomycosis, and monitored survival for 3 wk. We tested for possible interactions between UV-B and BD in 3 species: the Cascades frog Rana cascadae; the Western toad Bufo boreas; and the Pacific treefrog Hyla regilla. We found strong interspecific differences in susceptibility to BD. For example, $R$. cascadae suffered a large increase in mortality when exposed to BD; $B$. boreas also experienced mortality, but this effect was small relative to the $R$. cascadae response. $H$. regilla did not show any decrease in survival when exposed to either factor. No synergistic interactions between UV-B and BD were found for any of the test species. A previous study investigating the impact of BD on larval amphibians showed different species responses (Blaustein et al. 2005a). Our results highlight the importance of studying multiple life history stages when determining the impact of environmental stressors. The contrast between these 2 studies emphasizes how vulnerability to a pathogen can vary between life history stages within a single species.
\end{abstract}

KEY WORDS: Emerging infectious diseases · Batrachochytruim dendrobatadis · Ultraviolet radiation · Multiple stressors · Amphibian metamorph

- Resale or republication not permitted without written consent of the publisher

\section{INTRODUCTION}

The loss of biodiversity is a major international concern. The current rate of extinction may be greater than any known in the last 100000 years (Eldridge1998). Despite the recognition that there are complex dynamics contributing to species loss, studies often focus on the direct effects of single factors. This is illustrated in attempts to understand the global decline of amphibian populations (Houlahan et al. 2000, Stuart et al. 2004). Recent studies directed at this problem suggest that global amphibian losses are the result of interactions between a number of highly context-dependent causal factors (Alford \& Richards 1999, Blaustein \& Kiesecker
2002, Collins \& Storfer 2003), highlighting the need to investigate multiple stressors and synergistic impacts.

Major factors contributing to certain amphibian population declines include changes in atmospheric conditions and infectious diseases (Kiesecker \& Blaustein 1995, Pounds et al. 1999, Blaustein et al. 2001, Kiesecker et al. 2001, Pounds \& Puschendorf 2004, Pounds et al. 2006). Changes in temperature, cloud cover, precipitation patterns and changes in stratospheric ozone levels may all affect amphibians. In addition, several infectious diseases have been associated with amphibian population declines, such as oomycetes, fungi, bacteria and viruses (Drury et al. 1995, Jancovich et al. 1997, Haydon et al. 2002, Daszak et al. 2003). 
Batrachochytrium dendrobatidis (BD) is one emerging infectious disease that appears to be affecting amphibian populations on a global scale (Berger et al. 1999, Daszak et al. 2003). Many aspects of how this fungus interacts with amphibians are unknown. For example, the means and rate of transmission under field conditions, the prevalence of infection amongst amphibian populations and the overall effect of the fungus on amphibians in the wild are poorly understood (Nichols et al. 2001, Vredenburg \& Summers 2001, McCallum 2005). Furthermore, it is uncertain if $\mathrm{BD}$ is a novel pathogen or whether it has been chronically present with occasional disease outbreaks of chytridiomycosis, the disease caused by BD (Daszak et al. 2004, McCallum 2005, Ouellett et al. 2005, Rachowicz et al. 2005). Environmental co-factors could interact with $\mathrm{BD}$ to induce outbreaks, increase the virulence of BD directly, or hamper immune systems to increase the susceptibility of amphibian hosts.

Cofactors are implicated in the emergence and transmission of various pathogens infecting amphibians (Kiesecker \& Blaustein 1995, Cunningham et al. 1996, Taylor et al. 1999, Kiesecker \& Skelly 2001, Kiesecker et al. 2001, Kiesecker 2002, Blaustein \& Johnson 2003, Christin et al. 2003, Gendron et al. 2003, Johnson \& Chase 2004) including BD (Bosch et al. 2001, Pounds 2001, Parris \& Beaudoin 2004, Parris \& Cornelius 2004). Increasing UV radiation and contaminants from acid precipitation have been proposed as potential cofactors in outbreaks of BD (Blaustein \& Kiesecker 2002) in western North America. Ultraviolet B (UV-B) enhances the susceptibility of Bufo boreas eggs to oomycete infection (Kiesecker \& Blaustein 1995, Kiesecker et al. 2001) and may do the same when $\mathrm{BD}$ is present. In Colorado, where amphibians are especially sensitive to low pH (Harte \& Hoffman 1989, Kiesecker 1996), a number of $B$. boreas have been found with BD (Muths et al. 2003). Thus, amphibians in Colorado may be more prone to $\mathrm{BD}$ infection in the presence of episodic acidification (Harte \& Hoffman 1989).

In this paper, we investigated potential synergistic interactions between BD and UV-B (280 to $315 \mathrm{~nm}$ ) radiation. UV-B radiation is an environmental co-factor that may enhance the effects of BD for a number of reasons. UV-B radiation is often harmful to amphibians and can be lethal to some species at certain developmental stages (Blaustein \& Belden 2003). Moreover, UV-B may induce a number of sublethal effects in amphibians including physiological, developmental and behavioral anomalies (Blaustein et al. 2001). Stress from UV-B exposure may cause some amphibian species to become more susceptible to pathogenic infection. UV-B radiation interacts synergistically with at least one other pathogen, the oomycete Saprolegnia ferax, increasing mortality in amphibians when both UV-B and the pathogen are present (Kiesecker \& Blaustein 1995, Kiesecker et al. 2001).

Climatic conditions influence UV-B exposure rates and the effects of water-borne pathogens. For example, UV-B exposure rates are, in part, determined by water depth, which depends on winter precipitation. In the Oregon Cascade Range, winter precipitation is modified by El Niño/Southern Oscillation events, resulting in a link between large-scale climatic patterns and mortality from Saprolegnia ferax in amphibian populations (Kiesecker et al. 2001). It is reasonable to assume that other pathogens, such as BD, would interact similarly with UV-B radiation. Recently, it has been hypothesized that harlequin frog populations in tropical America have declined due to a complex interaction of global warming, changes in moisture gradients and BD outbreaks (Pounds et al. 2006).

\section{SYSTEM}

Recently metamorphosed individuals (metamorphs) of 3 amphibian species were used in this study: the Cascades frog Rana cascadae, the Western toad Bufo boreas and the Pacific treefrog Hyla regilla. These 3 species were chosen because they vary in their susceptibility to UV-B radiation (Blaustein et al. 1998). Testing amphibian species with differential sensitivity to UV-B radiation allows us to quantify the range of possible synergisms with BD. All 3 species have aquatic larval stages and co-occur throughout much of the Oregon Cascade Range.

Blaustein et al. (2005a) examined larval mortality in these 3 amphibian species in response to BD exposure. Bufo boreas tadpoles were highly susceptible to BD, often dying immediately after BD exposure. Rana cascadae larvae, however, did not suffer significant mortality after exposure to BD, nor did Hyla regilla larvae. Sensitivity to environmental stressors, however, often varies between life history stages, and susceptibility to pathogens at one stage does not denote susceptibility at all stages. For example, R. cascadae suffers heavy mortality when exposed to UV-B radiation in the egg stage, while exposure at the larval stage may cause more sub-lethal damage than mortality (Blaustein et al. 1998). B. boreas is sensitive to UV-B exposure in its embryonic stage (Blaustein et al. 1994a) and after metamorphosis (Blaustein et al. 2005b) but this species is relatively resilient to UV damage as larvae (Little et al. 2003). H. regilla, however, is less susceptible to UV$B$ damage at the embryo stage (Blaustein et al. 1998) compared to the other species tested in this study, while long-term exposure to ambient UV-B can induce physiological and developmental abnormalities in me- 
tamorphs and larvae (Hays et al. 1996). This study examined the effect of BD and UV-B exposure on the survival of metamorphs for all 3 species.

\section{MATERIALS AND METHODS}

Recently metamorphosed juvenile anurans were collected on September 2, 2005, from endemic breeding sites in the central Oregon Cascade Range: Rana cascadae and Hyla regilla at a sub-alpine meadow $2 \mathrm{~km}$ NW of Todd Lake, Deschutes County, Oregon, and Bufo boreas from Todd Lake, Deschutes County, Oregon. All animals were held at Oregon State University, Corvallis, Oregon, in a temperature-controlled room with natural photoperiod and fed crickets ad libitum during the $5 \mathrm{~d}$ holding period.

We used a $3 \times 2 \times 2$ factorial design; 3 species treatments (Rana cascadae, Bufo boreas and Hyla regilla), 2 UV-B treatments (present and absent) and 2 BD exposure treatments (present and absent). The experiment had 6 replicates per treatment combination (total $\mathrm{n}=72$ ), and metamorphs were randomly assigned to experimental units. Each experimental unit contained 5 metamorphs. Snout-vent lengths were measured on 14 metamorphs from each species $(R$. cascadae $=$ $15.42 \mathrm{~mm} \pm 0.36 ; \quad$ B. boreas $=21.99 \mathrm{~mm} \pm 0.31$; H. regilla $=19.49 \mathrm{~mm} \pm 0.40)$.

We first exposed metamorphs to UV-B treatments for $3 \mathrm{~d}$. Metamorphs were housed in round plastic cups (500 ml) with a damp paper towel at the bottom. Filters were used to manipulate UV-B exposure: Mylar filters excluded $95 \%$ of UV-B radiation (UV absent), and high-density polyethylene filters removed $15 \%$ of $\mathrm{UV}^{-} \mathrm{B}$ radiation (UV present). All units were placed in a UV-B chamber with constant temperature and photoperiod $\left(16^{\circ} \mathrm{C}, 12 \mathrm{~h}\right.$ light:12 h dark) equipped with UV-B emitting light bulbs. Exposures were carefully designed so that amphibians received UV-B exposure relevant to their natural environment yet below lethal levels (Blaustein et al. 1998, Blaustein et al. 2005b). Metamorphs received exposure rates between 16.2 and $17.9 \mu \mathrm{W} \mathrm{cm} \mathrm{cm}^{-2}$ in the UV present treatments and between 0.22 and $0.31 \mu \mathrm{W} \mathrm{cm}{ }^{-2}$ in the UV absent treatments.

To simulate a natural UV-B environment, our lighting regime consisted of a $12 \mathrm{~h}$ day but only $5 \mathrm{~h}$ of UV-B exposure. In the morning (first $3 \mathrm{~h}$ of daylight) and evening (last $4 \mathrm{~h}$ of daylight), metamorphs were exposed to only full spectrum bulbs emitting negligible levels of UV-B (Vita-Life; Durotest). During peak UV periods (11:00 to 16:00 h) metamorphs were exposed to UV-B emitting bulbs (UV-313; Q-Panel). UV-B was measured with a UV-B probe (model PMA2100, Solar Light).
BD treatments were applied immediately following UV-B exposure. Metamorphs from each experimental unit were transferred to corresponding Petri agar dishes that were either cultured with BD or left sterile. Each dish was flooded with $1.0 \mathrm{ml}$ of ultrapure $\mathrm{H}_{2} \mathrm{O}$ immediately prior to the addition of metamorphs and an additional $1.0 \mathrm{ml}$ was added $12 \mathrm{~h}$ later to allow for zoospore mobility. Dishes were covered with $2 \mathrm{~mm}^{2}$ mesh window screen and secured with rubber bands to prevent metamorphs from escaping and to force contact between the metamorph and the BD-covered Petri plate surface. After $24 \mathrm{~h}$ of exposure to BD, all metamorphs were transferred to clean Petri dishes (14 cm diameter, $2 \mathrm{~cm}$ tall) and monitored for a $3 \mathrm{wk}$ period. Paper towels were placed at the bottom of the dishes and constantly kept moist. Each individual was fed 3 crickets $\mathrm{wk}^{-1}$. Mortality was noted throughout the experiments, and dead metamorphs were removed. At the end of the experiment, surviving metamorphs were sacrificed. All metamorphs were preserved in $70 \%$ ethanol.

BD culturing methods. We used Batrachochytrium dendrobatidis isolate JEL 215 grown in pure culture on Petri agar dishes, according to standard protocol (Longcore et al. 1999). Petri dishes were incubated at $22^{\circ} \mathrm{C}$ for $11 \mathrm{~d}$ before use. Immediately prior to the experiment, all Petri dishes were inspected visually, and those with BD growth that appeared substantially more or less than that present in the majority of the dishes were excluded. Zoospores (the infective stage) were counted in a random sample using a cytometer, and the mean number of zoospores per dish $( \pm \mathrm{SE})$ were $2.08 \times 10^{7}\left( \pm 2.86 \times 10^{6}\right)$.

Statistical methods. Respective survival at 7,14 and $21 \mathrm{~d}$ post exposure to UV-B and BD treatments were analyzed using repeated measures multivariate analysis of variance (MANOVA). Survival was calculated by determining the percentage of surviving metamorphs in each experimental unit for all 3 exposure time points. All data were angular transformed. During the $3 \mathrm{~d}$ of UV-B exposure and prior to the UV-B exposure, 3 Bufo boreas metamorphs died in 3 separate experimental units. As a result, proportional B. boreas data was not available for use with the full model analysis. Only Hyla regilla and Rana cascadae data were compared for species survival differences. Each species, however, was analyzed separately using repeated measures MANOVAs to identify species-specific response to UV-B and BD over time.

\section{RESULTS}

Exposure to BD had a significant negative effect ( $\mathrm{p}<$ 0.05) on survival for Rana cascadae and Bufo boreas (Table 1, Fig. 1a,b). No UV-B effect or UV-B $\times$ BD inter- 
Table 1. Rana cascadae, Bufo boreas and Hyla regilla. Repeated measures MANOVA by species on UV-B and disease (Batrachochytrium dendrobatidis, BD) effects on survival. Between-subjects shows differences in overall survival, and within-subjects indicates survival over $3 \mathrm{wk}$. Num: numerator; Den: denominator. ${ }^{*}$ Statistically significant values $(\mathrm{p}<0.05)$

\begin{tabular}{|c|c|c|c|c|c|}
\hline Source & ${ }_{\text {Num }}^{\text {df }}$ & Den & MS & $F$ & $\mathrm{p}$ \\
\hline \multicolumn{6}{|l|}{ Rana cascadae } \\
\hline \multicolumn{6}{|l|}{ Between-subjects } \\
\hline UV-B & 1 & 20 & 0.009 & 0.184 & 0.672 \\
\hline Disease & 1 & 20 & 0.329 & 6.588 & $0.018^{*}$ \\
\hline UV-B $\times$ Disease & 1 & 20 & 0.001 & 0.014 & 0.908 \\
\hline \multicolumn{6}{|l|}{ Within-subjects } \\
\hline Time & 2 & 19 & 0.325 & 3.085 & 0.069 \\
\hline Time $\times$ UV-B & 2 & 19 & 0.016 & 0.152 & 0.859 \\
\hline Time $\times$ Disease & 2 & 19 & 0.009 & 0.091 & 0.913 \\
\hline Time $\times$ UV-B $\times$ Disease & 2 & 19 & 0.085 & 0.803 & 0.463 \\
\hline \multicolumn{6}{|l|}{ Bufo boreas } \\
\hline \multicolumn{6}{|l|}{ Between-subjects } \\
\hline UV-B & 1 & 20 & 0.003 & 0.062 & 0.805 \\
\hline Disease & 1 & 20 & 0.342 & 6.832 & $0.016^{*}$ \\
\hline UV-B $\times$ Disease & 1 & 20 & 0.003 & 0.062 & 0.805 \\
\hline \multicolumn{6}{|l|}{ Within-subjects } \\
\hline Time & 2 & 19 & 0.001 & 0.009 & 0.990 \\
\hline Time $\times$ UV-B & 2 & 19 & 0.003 & 0.029 & 0.971 \\
\hline Time $\times$ Disease & 2 & 19 & 0.342 & 3.245 & 0.061 \\
\hline Time $\times$ UV-B $\times$ Disease & 2 & 19 & 0.003 & 0.029 & 0.971 \\
\hline \multicolumn{6}{|l|}{ Hyla regilla } \\
\hline \multicolumn{6}{|l|}{ Between-subjects } \\
\hline UV-B & 1 & 20 & 0.05 & 1.0 & 0.329 \\
\hline Disease & 1 & 20 & 0.05 & 1.0 & 0.329 \\
\hline UV-B $\times$ Disease & 1 & 20 & 0.05 & 1.0 & 0.329 \\
\hline \multicolumn{6}{|l|}{ Within-subjects } \\
\hline Time & 2 & 19 & 0.00 & 0.000 & 1.000 \\
\hline Time $\times$ UV-B & 2 & 19 & 0.00 & 0.000 & 1.000 \\
\hline Time $\times$ Disease & 2 & 19 & 0.00 & 0.000 & 1.000 \\
\hline Time $\times$ UV-B $\times$ Disease & 2 & 19 & 0.00 & 0.000 & 1.000 \\
\hline
\end{tabular}

action was found for either R. cascadae, B. boreas or $H$. regilla (Table 1, Fig. 1). Species differed in their response to both disease and survival over time (Table 2). H. regilla responded to UV-B and BD with almost $100 \%$ survival, and $R$. cascadae experienced considerable mortality by the third week. Mortality in $R$. cascadae due to BD exposure was significant within the first week, but the impact of the disease effect decreased over time as control mortality increased. And while disease impacted $B$. boreas's survival, this effect did not change significantly over time (Table 1).

\section{DISCUSSION}

This study shows clear species-specific differences in response to BD. Rana cascadae metamorphs were highly susceptible to BD and died in large numbers
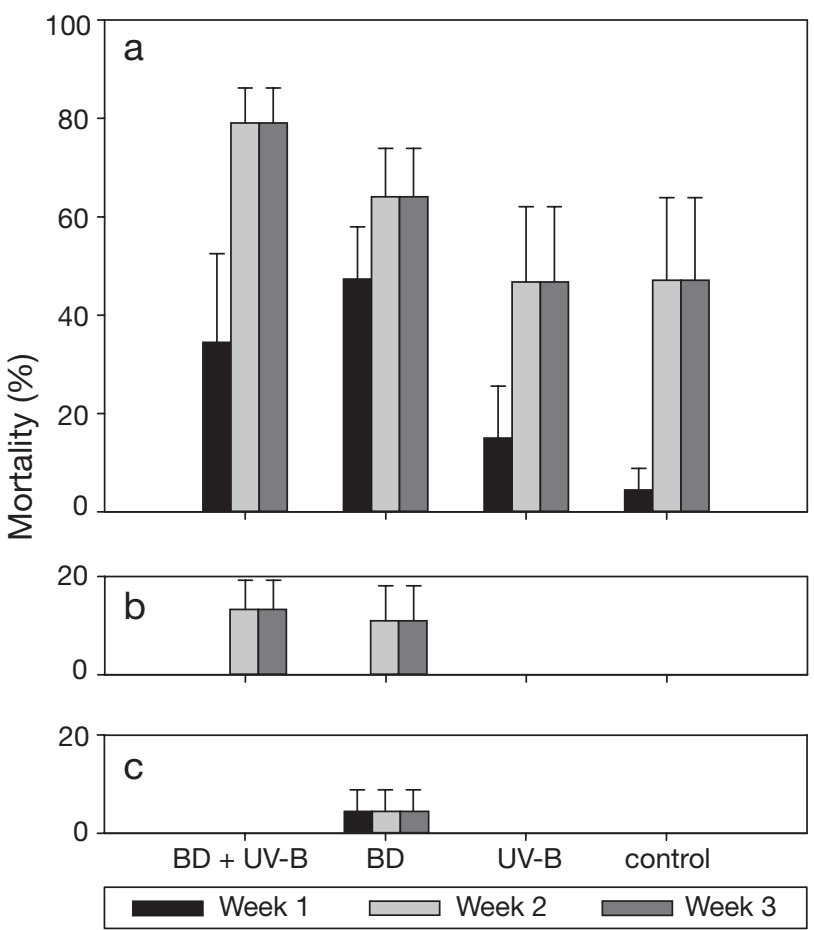

Fig. 1. Rana cascadae, Bufo boreas and Hyla regilla. Percent mortality of the metamorphic (a) Cascades frog, (b) Western toad and (c) Pacific treefrog exposed to Batrachochytrium dendrobatidis (BD) and UV-B radiation over a $3 \mathrm{wk}$ observation period. Error bars are $+\mathrm{SE}$, and data were angular transformed

within $1 \mathrm{wk}$ of exposure regardless of the presence of UV-B. Bufo boreas showed a similar trend with increased mortality after exposure to $\mathrm{BD}$, but overall the $B$. boreas mortality was relatively low compared to $R$. cascadae. Mortality did not increase when $H$. regilla metamorphs were exposed to BD or UV-B. Our results suggest that there are species-specific differences in susceptibility to BD and newly metamorphic anurans can be killed by exposure to BD. In addition, these results differ significantly from a previous study which tested the larval stage of these 3 species (Blaustein et al. 2005a). This can be interpreted to mean that within the same species, different life stages may show different sensitivities to BD.

Exposure to UV-B radiation did not significantly increase mortality in our study in any of the 3 species. Blaustein et al. (2005b) showed that ambient levels of UV-B killed newly metamorphosed Bufo boreas. In the present study, similar intensities of UV-B

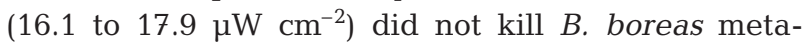
morphs. However, B. boreas in the previous study (Blaustein et al. 2005b) were exposed to UV-B for almost twice as long as those in our study, thus accounting for the differences in mortality. Our study was designed to limit the time of exposure, and sub- 
Table 2. Rana cascadae and Hyla regilla. Repeated measures MANOVA for UV-B and disease (Batrachochytrium dendrobatidis, BD) effects on anuran metamorphs. Between-subjects shows differences in survival between species, and withinsubjects indicates survival over 3 wk. Num: numerator; Den: denominator. ${ }^{*}$ Statistically significant values $(p<0.05)$

\begin{tabular}{|lccccc|}
\hline Source & \multicolumn{2}{c}{ df } & MS & $F$ & $p$ \\
& Num & Den & & & \\
\hline Between-subjects & & & & & \\
Species & 1 & 41 & 1.918 & 78.651 & $<0.0001^{*}$ \\
UV-B & 1 & 41 & 0.001 & 0.046 & 0.831 \\
Disease & 1 & 41 & 0.184 & 7.555 & $0.008^{*}$ \\
Species $\times$ UV-B & 1 & 41 & 0.009 & 0.403 & 0.529 \\
Species $\times$ Disease & 1 & 41 & 0.132 & 5.425 & $0.025^{*}$ \\
UV-B $\times$ Disease & 1 & 41 & 0.0002 & 0.009 & 0.926 \\
Within-subjects & & & & & \\
Time & 2 & 40 & 0.169 & 3.394 & $0.043^{*}$ \\
Time $\times$ Species & 2 & 40 & 0.495 & 9.899 & $0.0003^{*}$ \\
Time $\times$ UV-B & 2 & 40 & 0.007 & 0.154 & 0.858 \\
Time $\times$ Disease & 2 & 40 & 0.005 & 0.092 & 0.912 \\
Time $\times$ Species $\times$ UV-B & 2 & 40 & 0.008 & 0.154 & 0.858 \\
Time $\times$ Species $\times$ Disease & 2 & 40 & 0.005 & 0.092 & 0.912 \\
Time $\times$ UV-B $\times$ Disease & 2 & 40 & 0.041 & 0.811 & 0.452 \\
\hline
\end{tabular}

sequent mortality from UV-B, based on the results of previous work (Blaustein et al. 2005b).

We found no evidence for synergistic interaction between BD and UV-B on survival in the 3 test species. However, it is reasonable to assume that synergistic effects between UV-B and other factors may occur in these species. For example, previous work on Hyla regilla showed synergistic effects between contaminants and UV-B (Blaustein et al. 2003) and pathogens and UV-B in Bufo boreas (Kiesecker et al. 2001). However, $H$. regilla is more resistant to UV-B than the other species we examined (Blaustein et al. 1994a,1998). Because $H$. regilla is relatively resistant to UV-B, it is not surprising that $H$. regilla metamorphs had high survival in our study compared with the other species. $B$. boreas metamorphs did not suffer a significant increase in mortality in UV-B exposed treatments, but longer exposure to UV-B may be necessary to observe a detrimental synergistic interaction. Any interaction between UV-B and BD in Rana cascadae metamorphs, however, was difficult to detect due to the high mortality in treatments with BD. This result should not be interpreted to mean UV-B does not play a synergistic role with disease in $R$. cascadae; further investigation quantifying dose-dependent responses is needed. High background mortality in $R$. cascadae may have been caused by high stress levels due to capture and handling, which is characteristic of this species (Belden et al. 2003).

These results provide additional data on the effects of $\mathrm{BD}$ on different life history stages and different species of anuran amphibians. Blaustein et al. (2005a) showed that larval Bufo boreas were highly susceptible to BD exposure, and that a toxic substance produced from BD probably caused mortality in these toad larvae. However, in our study, B. boreas metamorphs, while showing an increase in mortality when exposed to $\mathrm{BD}$, did not experience a massive die-off. $R$. cascadae metamorphs, however, were highly vulnerable to mortality from BD exposure in this study, but larval R. cascadae in our earlier study (Blaustein et al. 2005a) were not. Neither $H$. regilla larvae (Blaustein et al. 2005a) nor their metamorphs (our study) showed increased mortality as a result of BD exposure. This difference in susceptibility to BD and life stage illustrates the need to test all stages of anuran development when assessing effects of environmental stressors.

The mechanisms by which BD kills amphibians are poorly understood. One hypothesis suggests that the fungus produces lethal toxins, whereas another suggests that infection disrupts skin function, thus affecting respiration and osmoregulation (Berger et al. 1998). These 2 mechanisms may work together (Daszak et al. 1999). BD has a 4 d generation time in culture (Longcore et al. 1999, Piotrowski et al. 2004). Anuran metamorphs do not typically die, at least in laboratory tests, from chytridiomycosis until approximately 2 wk after initial BD exposure (Nichols et al. 2001, Carey et al. 2006). In the present study, Rana cascadae larvae and metamorphs began dying within $48 \mathrm{~h}$ after exposure to BD (Blaustein et al. 2005a, present study). These results and those reported previously suggest the possibility that a toxin, and not chytridiomycosis, was involved in causing mortality in metamorphic and larval stages.

The ecological parameters influencing susceptibility of amphibians to BD in nature are largely unknown. $\mathrm{BD}$ is widespread and found in amphibian populations in the tropics as well as in temperate regions (Daszak et al. 2003). Different strains of BD may be genetically similar (Morehouse et al. 2003). However, even though the strains are similar, they may affect various species and populations of amphibians differently. This could explain why some amphibian populations are more vulnerable to mass mortality events associated with $\mathrm{BD}$, whereas other populations appear robust despite the presence of infected animals.

Susceptibility to BD after metamorphosis is significant for several reasons. Our results suggest that not only can metamorphs be reservoirs for disease transmission, but they may also die directly from exposure. This could occur under a variety of scenarios when anurans congregate (Blaustein \& Walls 1995). For example, large numbers of frogs and toads may synchronously metamorphose (Neill 1957, Arnold \& Wassersug 1978) with individuals having close contact with many others, such as Bufo boreas (Blaustein et 
al. 2005b). Aggregations of frogs and toads may occur when they are under physiological stress (Johnson 1969). In many species, large aggregations of breeding adults may occur (Sullivan et al. 1995). Impacts of increased metamorph mortality from BD on overall population growth rates may also be significant. Metamorph survival has a strong influence on the population dynamics of many anuran species relative to larval survival (Wilbur 1980, Biek et al. 2002). The susceptibility of metamorphs to BD could have significant consequences on declining amphibian populations.

The possibility of non-amphibian substrates as a reservoir of BD must be considered (Johnson \& Speare 2003). Some pathogens, such as the water mold Saprolegnia ferax (Blaustein et al. 1994b), may be present continually in the environment because they are saprobes. Persistence of BD as a saprobe would have essentially the same effect as a host reservoir. That is, BD could persist in amphibian habitats between outbreaks (Daszak et al. 2003).

We have now examined the effects of BD on 2 life history stages in several species of anuran amphibians. Our results suggest that the larval stage of one species, Bufo boreas (Blaustein et al. 2005a), is more susceptible to BD than the metamorph stage. In another species, Rana cascadae, post-metamorphic stages were more susceptible to BD than were the larvae. Other species were unaffected after exposure to BD at any stage. The questions arising from these differences in susceptibility would suggest that we should examine different species and different life stages to determine how BD affects amphibians.

Acknowledgements. We acknowledge R. Hill and K. Tonsfeld for their tireless effort in the field and lab, and the Blaustein lab for helpful comments on the manuscript. We especially thank C. Larson, T. Larson, A. Larson and H. Larson for their help. We thank M. Kavanaugh for her help with the statistical analysis and J. E. Longcore, who was helpful at all stages and provided much insight into the biology of Batrachochytrium. Funding was provided by grants from The NSF IRCEB Program (DEB0213851 and IBN9977063). We thank members of the Arizona State University NSF IRCEB grant for discussion.

\section{LITERATURE CITED}

Alford RA, Richards SJ (1999) Global amphibian declines: a problem in applied ecology. Annu Rev Ecol Syst 30: 133-165

Arnold SJ, Wassersug RJ (1978) Differential predation on metamorphic anurans by garter snakes (Thanophis): social behavior as a possible defense. Ecology 59: 1014-1022

Belden LK, IT Moore, RT Mason, JC Wingfield, AR Blasutein (2003) Survival, the hormonal stress response and UV-B avoidance in Cascades frog tadpoles (Rana cascadae) exposed to UV-B radiation. Funct Ecol 17(3):409-413
Berger L, Speare R, Daszak P, Green DE and 10 others (1998) Chytridiomycosis causes amphibian mortality associated with population declines in the rain forests of Australia and Central America. Proc Natl Acad Sci USA 95: 9031-9036

Berger L, Speare R, Hyatt A (1999) Chytrid fungi and amphibian declines: overview, implications, and future directions. In: Campbell A (ed) Declines and disappearances of Australian frogs. Environmental Australia, Canberra

Biek R, WC Funk, BA Maxell, LS Mills (2002) What is missing in amphibian decline research: insights from ecological sensitivity analysis. Conserv Biol 16:728-732

Blaustein AR, Belden LK (2003) Amphibian defenses against ultraviolet-B radiation. Evol Dev 5:89-97

Blaustein AR, Johnson PTJ (2003) The complexity of deformed amphibians. Front Ecol Environ 1:87-94

Blaustein AR, Kiesecker JM (2002) Complexity in conservation: lessons from the global decline of amphibian populations. Ecol Lett 5:597-608

Blaustein AR, Walls SC (1995) Aggregation and kin recognition. In: Heatwole H, Sullivan BK (ed) Amphibian biology, Vol 2. Social behavior. Surrey, Beatty and Sons, Chipping Norton

Blaustein AR, Hoffman PD, Hokit DG, Kiesecker JM, Walls SC, Hays JB (1994a) UV repair and resistance to solar UV$\mathrm{B}$ in amphibian eggs: a link to population declines? Proc Natl Acad Sci USA 91:1791-1795

Blaustein AR, Hokit DG, O'Hara RK, Holt RD (1994b) Pathogenic fungus contributes to amphibian losses in the Pacific Northwest. Biol Conserv 67:251-254

Blaustein AR, Kiesecker JM, Chivers DP, Hokit DG, Marco A, Belden LK, Hatch A (1998) Effects of ultraviolet radiation on amphibians: field experiments. Am Zool 38(6):799-812

Blaustein AR, Belden LK, Hatch AC, Kats LB and 5 others (2001) Ultraviolet radiation and amphibians. In: Cockell CS, Blaustein AR (ed) Ecosystems, evolution and ultraviolet radiation. Springer, New York

Blaustein AR, Romansic JR, Kiesecker JM, Hatch AC (2003) Ultraviolet radiation, toxic chemicals, and amphibian population declines. Divers Distrib 9:123-140

Blaustein AR, Romansic JR, Scheessele EA, Han BA, Pessier AP, Longcore JE (2005a) Interspecific variation in susceptibility of frog tadpoles to the pathogenic fungus, Batrachochytrium dendrobatidis. Conserv Biol 19:1460-1468

Blaustein AR, Romansic JM, Scheessele EA (2005b) Ambient levels of ultraviolet-B radiation cause mortality in juvenile western toads, Bufo boreas. Am Midl Nat 154:375-382

Bosch J, Martínez-Solano I, García-París M (2001) Evidence of a chytrid fungus infection involved in the decline of the common midwife toad (Alytes obstetricans) in protected areas of central Spain. Biol Conserv 97:331-337

Carey C, JE Bruzgul, LJ Livo, ML Walling and 5 others (2006) Experimental exposures of boreal toads (Bufo boreas) to a pathogenic chytrid fungus (Batrachochytrium dendrobatidis). EcoHealth 3:5-21

Christin MS, Gendron AD, Brousseau P, Menard L, Marcogliese DJ, Cyr D, Ruby S, Fournier M (2003) Effects of agricultural pesticides on the immune system of Rana pipiens and on its resistance to parasitic infection. Environ Toxicol Chem 22:1127-1133

Collins JP, Storfer A (2003) Global amphibian declines: sorting the hypotheses. Divers Distrib 9:89-98

Cunningham AA, Langton TES, Bennett PM, Lewin JF, Drury SEN, Gough RE, MacGregor SK (1996) Pathological and microbiological findings from incidents of unusual mortality of the common frog (Rana temporaria). Phil Trans R Soc Lond Ser B 351:1539-1557 
Daszak P, Berger L, Cunningham AA, Hyatt AD, Green DE, Speare R (1999) Emerging infectious diseases and amphibian population declines. Emerg Infect Dis 5: 735-748

Daszak P, Cunningham AA, Hyatt AD (2003) Infectious disease and amphibian population declines. Divers Distrib 9: $141-150$

Daszak P, Strieby A, Cunningham AA, Longcore JE, Brown CC, Porter D (2004) Experimental evidence that the bullfrog (Rana catesbeiana) is a carrier of chytridiomycosis, an emerging fungal disease of amphibians. Herpetol J 14(4): 201-207

Drury SEN, Gough RE, Cunningham AA (1995) Isolation of an iridovirus-like agent from common frogs (Rana temporaria). Vet Rec 137:72-73

Eldridge N (1998) Life in the balance: humanity and the biodiversity crisis. Princeton University Press, Princeton, NJ

Gendron AD, Marcogliese DJ, Barbeau S, Christin MS, Brousseau P, Ruby S, Cyr D, Fournier M (2003) Exposure of leopard frogs to a pesticide mixture affects life history characteristics of the lungworm Rhadbais ranae. Oecologia 135:469-476

Harte J, Hoffman E (1989) Possible effects of acidic deposition on a Rocky Mountain population of the tiger salamander Ambystoma tigrinum. Conserv Biol 3:149-158

Haydon DT, Cleaveland S, Taylor LH, Laurenson MK (2002) Identifying reservoirs of infection: a conceptual and practical challenge. Emerg Infect Dis 8:1468-1473

Hays JB, Blaustein AR, JM Kiesecker, PD Hoffman, I Pandelova, D Coyle, T. Richardson (1996) Developmental responses of amphibians to solar and artificial UVB sources: a comparative study. Photochem Photobiol 64(3):449-456

Houlahan JE, Findlay CS, Scmidt BR, Myer AH, Kuzmin SL (2000) Quantitative evidence for global amphibian population declines. Nature 404:752-755

Jancovich JK, Davidson EW, Morado JF, Jacobs BL, Collins JP (1997) Isolation of a lethal virus from the endangered tiger salamander Ambystoma tigrinum stebbensi. Dis Aquat Org 31:161-167

Johnson CR (1969) Aggregation as a means of water conservation in juvenile Limnodynastes from Australia. Herpetologica 25:275-276

Johnson M, Speare R (2003) Survival of Batrachochytrium dendrobatidis in water: quarantine and control implications. Emerg Infect Dis 9:922-925

Johnson PTJ, Chase JM (2004) Parasites in the food web: linking amphibian malformations and aquatic eutrophication. Ecol Lett 7:521-526

Kiesecker JM (1996) pH-mediated predator-prey interactions between Ambystoma tigrinum and Pseudacris triseriata. Ecol Appl 6:1325-1331

Kiesecker JM (2002) Synergism between trematode infection and pesticide exposure: a link to amphibian limb deformities in nature? Proc Natl Acad Sci USA 99:9900-9904

Kiesecker JM, Blaustein AR (1995) Synergism between UV-B radiation and a pathogen magnifies amphibian embryo mortality in nature. Proc Natl Acad Sci USA 92: 11049-11052

Kiesecker JM, Skelly DK (2001) Effects of disease and pond drying on gray tree frog growth, development and survival. Ecology 82:1956-1963

Kiesecker JM, Blaustein AR, Belden LK (2001) Complex causes of amphibian population declines. Nature 410:681-684

Little EE, Calfee RD, Fabrasher DL, Carey C, Blazer VS, Middleton EM (2003) Effects of ultraviolet radiation on toad early life stages. Environ Sci Pollut Res Int 10(3):167-172 Longcore JE, Pessier AP, Nichols DK (1999) Batrachochytrium dendrobatidis. gen. et. sp. nov., a chytrid pathogenic to amphibians. Mycologia 91:219-227

McCallum H (2005) Inconclusiveness of chytridiomycosis as the agent in widespread frog declines. Conserv Biol 19(5): 1421-1430

Morehouse EA, James TY, Ganley ARD, Vilgalys T, Berger L, Murphy PJ, Longcore JE (2003) Multilocus sequence typing suggests the chytrid pathogen of amphibians is a recently emerged clone. Mol Ecol 12:395-403

Muths E, Corn PS, Pessier AP, Green DE (2003) Evidence for disease-related amphibian decline in Colorado. Biol Conserv 110:357-365

Neill WT (1957) Notes on metamorphic and breeding aggregations of the easter spadefoot, Scaphiopus holbrooki (Harlan). Herpetologica 13:185-187

Nichols DK, Lamirande EW, Pessier AP, Longcore JE (2001) Experimental transmission of cutaneous chytridiomycosis in dendrobatid frogs. J Wildl Dis 37:1-11

Ouellett M, Mikaelian I, Pauli BD, Rodrigue J, Green DM (2005) Historical evidence of widespread chytrid infection in North American amphibian populations. Conserv Biol 19(5):1431-1440

Parris MJ, Beaudoin JG (2004) Chytridiomycosis impacts predator-prey interactions in larval amphibian communities. Oecologia 140:626-632

Parris MJ, Cornelius TO (2004) Fungal pathogen causes competitive and developmental stress in larval amphibian communities. Ecology 85:3385-3395

Piotrowski JS, Annis SL, Longcore JE (2004) Physiology of Batrachochytrium dendrobatidis, a chytrid pathogen of amphibians. Mycologia 9:9-15

Pounds JA (2001) Climate and amphibian declines. Nature 410:639-640

Pounds JA, Puschendorf R (2004) Clouded futures. Nature 427:107-109

Pounds JA, Fogden MPL, Campbell JH (1999) Biological response to climate change on a tropical mountain. Nature 398:611-615

Pounds JA, Bustamante MR, Coloma LA, Consuergra JA and 10 others (2006) Widespread amphibian extinctions from epidemic disease driven by global warming. Nature 439: 161-167

Rachowicz LJ, Hero JM, Alford RA, Taylor JW, Morgan JAT, Vredenburg VT, Collins JP, Briggs CJ (2005) The novel and endemic pathogen hypothesis: competing explanations for the origin of emerging infection diseases of wildlife. Conserv Biol 19(5):1441-1448

Stuart SN, Chanson JS, Cox NA, Young BE, Rodrigues ASL, Fischman DL, Waller RW (2004) Status and trends of amphibian declines and extinctions worldwide. Science 306:1783-1786

Sullivan BK, Ryan MJ, Verrell PA (1995) Female choice and mating system structure. In: Heatwole H, Sullivan BK (ed) Amphibian biology, Vol 2. Social behavior. Surrey, Beatty and Sons, Chipping Norton

Taylor SK, Williams ES, Mills KW (1999) Effects of malathion on disease susceptibility in Woodhouse's toads. J Wildl Dis 35:536-541

Vredenburg VT, Summers AP (2001) Field identification of chytridiomycosis in Rana muscosa (Camp 1915). Herpetol Rev 32:151-152

Wilbur H (1980) Complex life cycles. Annu Rev Ecol Syst 11: $67-93$

Submitted: February 7, 2006; Accepted: May 30, 2006

Proofs received from author(s): October 10, 2006 